\title{
HQSAR Analysis on Novel series of 1-(4-Phenylpiperazin-1-yl-2- (1H-Pyrazol-1-yl) Ethanone Derivatives Targeting CCR1
}

\author{
Pavithra K. Balasubramanian ${ }^{1 \dagger}$ and Seung Joo Cho ${ }^{1,2 \dagger}$
}

\begin{abstract}
The chemokine receptor CCR1 a GPCR super family protein contains seven transmembrane domains. It plays an important role in rheumatoid arthritis, organ transplant rejection, Alzheimer's disease and also causes inflammation. Because of its role in disease processes, antagonism of CCR1 became an attractive therapeutic target. In the current study, we have taken a novel series of recently reported CCR1 antagonist of 1-(4-Phenylpiperazin-1-yl_-2-(1H-Pyrazol-1-yl) ethanone derivatives and performed a HQSAR analysis. The model was developed with Atom (A) and bond (B) parameters and with different set of atom counts to improve the model. The results of HQSAR showed good predictive ability in terms of $r^{2}(0.904)$ and $q^{2}(0.590)$ with 0.710 as standard error of prediction and 0.344 as standard error of estimate. The contribution map depicted the atom contribution in inhibitory effect. Compound-14 which was reported to be a highly active compound showed positive atom contribution in three $R$ groups $\left(R^{3} \cdot R^{5 a}\right.$ and $\left.R^{2 b}\right)$ in inhibitory effect, which could be the reason why this compound is highly active compound whereas, the lowest active compound- 6 showed negative contribution to inhibitory effect.
\end{abstract}

Key words: CCR1, HQSAR, GPCR, Ethanone Derivatives

\section{Introduction}

Chemokines are a family of structurally related molecules that serve primarily to facilitate leucocyte attraction and migration ${ }^{[1,2]}$. Chemokines are produced by a wide variety of cells, which includes professional immune cells, tissue cells and intrinsic renal cells ${ }^{[1,3]}$. Chemokines are small water-soluble proteins approximately 8-10 kDa consisting of 340-380 amino acid residues. Chemokines produce various leukocyte responses liable on the complementary nature of their chemokine receptors ${ }^{[4,5]}$.

Chemokines effectively mediate inflammation by the recruitment and activation of specific leukocyte subpopulations such as macrophages, T and B lymphocytes, eosinophils, basophils and neutrophils ${ }^{[6]}$. The biological activities of CCR1 is exerted by binding to specific

\footnotetext{
${ }^{1}$ Departments of Bio-New Drug Development, College of Medicine, Chosun University, Gwangju 501-759, Korea

${ }^{2}$ Departments of Cellular-Molecular Medicine, College of Medicine, Chosun University, Gwangju 501-759, Korea

${ }^{\dagger}$ Corresponding author : pavithrabioinfo@gmail.com, chosj@chosun.ac.kr

(Received : September 4, 2013, Revised : September 16, 2013 , Accepted : September 23, 2013)
}

chemokine receptors belonging to the $\mathrm{G}$ protein-coupled receptor (GPCR) superfamily on the target cell plasma membrane. Based on the arrangement of two conserved cysteine residues near the $\mathrm{N}$-terminus, Chemokines are divided into four subfamilies (CC, CXC, C and $\mathrm{CX} 3 \mathrm{C})^{[7-9]}$. Few family members are also involved in viral entry and angiogenesis ${ }^{[10]}$. It was also reported that, a subset of chemokine receptors plays a non-redundant role in infectious diseases, as proven by resistance to human immunodeficiency virus/acquired immunodeficiency syndrome (HIV/AIDS) in CCR5 homozygous people $e^{[11-15]}$.

The chemokine receptor CCR1 belongs to GPCR super family that contains seven transmembrane domains $^{[16]}$. CCR1, the first CC Chemokine receptor to be identified, plays important role in host defense and inflammation. Antagonism of CCR1 is an attractive therapeutic target because of its role in rheumatoid arthritis, organ transplant rejection, Alzheimer's disease in terms of disease processes ${ }^{[17]}$. Chemokine receptor 1 (CCR1) is predominantly expressed on monocytes, $\mathrm{T}$ cells, dendritic cells and neutrophils. The CCR1 protein consists of 355 amino acid residues and belongs to the peptide subfamily of the Class-A GPCR family. At least 
11 different ligands (chemokines) interact with CCR1, including CCL3 (MIP-1 $\alpha$ ), CCL5 (RANTES), CCL7 (MCP-3), CCL8 (MCP-2), CCL14 (hemofiltrate CC chemokine-1), CCL15 (leukotactin-1), CCL16 (hemofiltrate CC chemokine-4) and CCL23 (myeloid progenitor inhibitory factor-1). Although this apparent redundancy and randomness may complicate the valuation of the roles of chemokines and receptors in different tissues and disease stages, the biological effects of the two main CCR1 ligands CCL3 (MIP-1 $\alpha$ ) and CCL5 (RANTES) play important roles in the development and progression of autoimmune diseases. Thus, the role of CCL3 and CCL5 in multiple sclerosis ${ }^{[18,19]}$, rheumatoid arthritis (RA) ${ }^{[20-22]}$, psoriasis ${ }^{[23]}$ and the induction of robust cell infiltration in vivo are believed to be facilitated mainly through CCR1.

Several small molecule antagonists of CCR1 have been described to date. Recently, Zhang et al., reported a series of 1-(4-Phenylpiperazin-1-yl_-2-(1H-Pyrazol-1yl) ethanone derivatives targeting CCR $1^{[29]}$ which was taken for the present study. Previously our group has reported several short reviews covering different in silico applications such as Pseudoreceptors, development of search algorithm in docking and importance of partial charges $^{[24-28]}$. Continuing the group effort, in the present work, HQSAR was used to develop a model to identify the vital group or atom that cause CCR1 antagonism. Our result could be helpful to find novel 1-(4-Phenylpiperazin-1-yl-2-(1H-Pyrazol-1-yl) ethanone derivatives.

\section{Experimental Sections}

\subsection{Dataset}

The dataset was selected from reported literature ${ }^{[29]}$ comprised of 56 compounds (Table 1, $2 \& 3$ ). The Inhibitor constant values were converted to minus logarithmic scale value $\left(\mathrm{pIC}_{50}\right)$ as a dependent variable for HQSAR by using the formula $\mathrm{pIC}_{50}=-\log \left(\mathrm{IC}_{50}\right)$. Compounds 32,51 and 53 were considered as outliers and were excluded from the dataset to avoid overfitting. All the molecules were built using Sketch program in Sybylx 2.0 and their energies were minimized using Tripos force field. The dataset was then used for HQSAR analysis.

\subsection{HQSAR}

HQSAR (Hologram QSAR) offers the ability to rap-
Table 1. Structure and biological values of 1-(4phenylpiperazin-1-yl_-2-(1H-pyrazol-1-yl) ethanone derivatives targeting CCR1

\begin{tabular}{|c|c|c|c|c|}
\hline $\mathrm{R}^{4}$ & $\mathrm{R}^{6}$ & & $\mathrm{H}_{3} \mathrm{C}^{\prime}$ & $\mathrm{CF}_{3}$ \\
\hline Compound & $\mathrm{R}^{3}$ & $\mathrm{R}^{4}$ & $\mathrm{R}^{5}$ & $\mathrm{pIC}_{50}$ \\
\hline 1. & $\mathrm{H}$ & $\mathrm{F}$ & $\mathrm{H}$ & 6.512 \\
\hline 2. & $\mathrm{H}$ & $\mathrm{H}$ & $\mathrm{H}$ & 5.251 \\
\hline 3. & $\mathrm{H}$ & $\mathrm{Cl}$ & $\mathrm{H}$ & 7.008 \\
\hline 4. & $\mathrm{H}$ & $\mathrm{Br}$ & $\mathrm{H}$ & 6.739 \\
\hline 5. & $\mathrm{H}$ & $\mathrm{Me}$ & $\mathrm{H}$ & 5.437 \\
\hline 6. & $\mathrm{H}$ & $\mathrm{OMe}$ & $\mathrm{H}$ & 4.494 \\
\hline 7. & $\mathrm{H}$ & $\mathrm{CF}_{3}$ & $\mathrm{H}$ & 5.008 \\
\hline 8. & $\mathrm{H}$ & $\mathrm{NO}_{2}$ & $\mathrm{H}$ & 5.248 \\
\hline 9. & $\mathrm{H}$ & $\mathrm{SO}_{2} \mathrm{Me}$ & $\mathrm{H}$ & 5.193 \\
\hline 10 & $\mathrm{Me}$ & $\mathrm{H}$ & $\mathrm{H}$ & 5.481 \\
\hline 11. & $\mathrm{OMe}$ & $\mathrm{H}$ & $\mathrm{H}$ & 5.568 \\
\hline 12. & $\mathrm{Cl}$ & $\mathrm{H}$ & $\mathrm{H}$ & 4.958 \\
\hline 13. & $\mathrm{Me}$ & $\mathrm{Cl}$ & $\mathrm{H}$ & 7.000 \\
\hline 14. & $\mathrm{OMe}$ & $\mathrm{Cl}$ & $\mathrm{H}$ & 8.397 \\
\hline 15. & OEt & $\mathrm{Cl}$ & $\mathrm{H}$ & 7.920 \\
\hline 16. & $\mathrm{O}-\mathrm{i}-\mathrm{Pr}$ & $\mathrm{Cl}$ & $\mathrm{H}$ & 7.113 \\
\hline 17. & $\mathrm{OMe}$ & $\mathrm{Cl}$ & $\mathrm{Me}$ & 6.970 \\
\hline 18. & $\mathrm{OMe}$ & $\mathrm{Cl}$ & $\mathrm{F}$ & 8.301 \\
\hline 19. & $\mathrm{OMe}$ & $\mathrm{Cl}$ & $\mathrm{Cl}$ & 8.000 \\
\hline 20. & $\mathrm{OMe}$ & $\mathrm{Cl}$ & $\mathrm{Br}$ & 7.853 \\
\hline 21. & $\mathrm{OMe}$ & $\mathrm{Cl}$ & $\mathrm{CO}_{2} \mathrm{H}$ & 6.376 \\
\hline 22. & $\mathrm{OMe}$ & $\mathrm{Cl}$ & $\mathrm{CONH}_{2}$ & 7.284 \\
\hline 23. & $\mathrm{OMe}$ & $\mathrm{Cl}$ & CONHMe & 6.677 \\
\hline 24. & $\mathrm{OMe}$ & $\mathrm{Cl}$ & $\mathrm{CONMe}_{2}$ & 6.657 \\
\hline 25. & $\mathrm{OMe}$ & $\mathrm{Cl}$ & $\mathrm{CH}_{2} \mathrm{OH}$ & 7.920 \\
\hline 26. & $\mathrm{OMe}$ & $\mathrm{Cl}$ & $\mathrm{CH}_{2} \mathrm{NH}_{2}$ & 7.795 \\
\hline
\end{tabular}

idly and easily generate QSAR models of high statistical quality and predictive value. HQSAR does not require the 3D Structure of Bioactive conformation. The Principle of HQSAR is that since the structure of the molecule is encoded within its 2D Fingerprint and that structure is the key determinant of all molecular properties including the biological activity, it should be possible to predict the activity of the molecule from its 
Table 2. Structure and biological values of 1-(4phenylpiperazin-1-yl_-2-(1H-pyrazol-1-yl) ethanone derivatives targeting CCR1

\begin{tabular}{|c|c|c|c|c|}
\hline $\mathrm{MeO}$ & & & $\mathrm{R}^{5 a}$ & $R^{3 a}$ \\
\hline Compound & $\mathrm{R}^{3 \mathrm{a}}$ & $\mathrm{R}^{4 \mathrm{a}}$ & $\mathrm{R}^{5 \mathrm{a}}$ & $\mathrm{pIC}_{50}$ \\
\hline 14 & $\mathrm{CF}_{3}$ & $\mathrm{Cl}$ & $\mathrm{Me}$ & 8.397 \\
\hline 27. & $\mathrm{CF}_{3}$ & $\mathrm{H}$ & $\mathrm{Me}$ & 7.721 \\
\hline 28. & $\mathrm{CF}_{3}$ & $\mathrm{~F}$ & $\mathrm{Me}$ & 8.301 \\
\hline 29. & $\mathrm{CF}_{3}$ & $\mathrm{Br}$ & $\mathrm{Me}$ & 8.096 \\
\hline 30. & $\mathrm{CF}_{3}$ & I & $\mathrm{Me}$ & 8.154 \\
\hline 31. & $\mathrm{CF}_{3}$ & $\mathrm{CN}$ & $\mathrm{Me}$ & 8.221 \\
\hline 32. & $\mathrm{CF}_{3}$ & NHAc & $\mathrm{Me}$ & 6.301 \\
\hline 33. & $\mathrm{CF}_{3}$ & $\mathrm{Cl}$ & $\mathrm{H}$ & 7.744 \\
\hline 34. & $\mathrm{CF}_{3}$ & $\mathrm{Cl}$ & $\mathrm{CF}_{3}$ & 6.130 \\
\hline 35. & $\mathrm{CF}_{3}$ & $\mathrm{Cl}$ & i-Pr & 5.958 \\
\hline 36. & $\mathrm{CF}_{3}$ & $\mathrm{Cl}$ & $\mathrm{Ph}$ & 5.468 \\
\hline 37. & $\mathrm{CF}_{3}$ & $\mathrm{Cl}$ & $\mathrm{CH}_{2} \mathrm{OH}$ & 8.000 \\
\hline 38. & $\mathrm{CF}_{3}$ & $\mathrm{Cl}$ & $\mathrm{CH}_{2} \mathrm{NH}_{2}$ & 7.301 \\
\hline 39. & $\mathrm{CF}_{3}$ & $\mathrm{Cl}$ & $\mathrm{CH}_{2} \mathrm{NMe}_{2}$ & 7.327 \\
\hline 40. & $\mathrm{CF}_{3}$ & $\mathrm{Cl}$ & $\mathrm{CH}_{2} \mathrm{NHAc}$ & 7.167 \\
\hline 41. & $\mathrm{H}$ & $\mathrm{Cl}$ & $\mathrm{Me}$ & 6.920 \\
\hline 42. & $\mathrm{Me}$ & $\mathrm{Cl}$ & $\mathrm{Me}$ & 7.397 \\
\hline 43. & i-Pr & $\mathrm{Cl}$ & $\mathrm{Me}$ & 8.096 \\
\hline 44. & $2 \mathrm{OH}-\mathrm{i}-\mathrm{Pr}$ & $\mathrm{Cl}$ & $\mathrm{Me}$ & 7.795 \\
\hline 45. & $\mathrm{Br}$ & $\mathrm{Cl}$ & $\mathrm{Me}$ & 7.699 \\
\hline 46. & $\mathrm{CN}$ & $\mathrm{Cl}$ & $\mathrm{Me}$ & 8.000 \\
\hline 47. & $\mathrm{SO}_{2} \mathrm{Me}$ & $\mathrm{Cl}$ & $\mathrm{Me}$ & 8.000 \\
\hline 48. & $\mathrm{NH}_{2}$ & $\mathrm{Cl}$ & $\mathrm{Me}$ & 6.468 \\
\hline 49. & $\mathrm{CH}_{2} \mathrm{OH}$ & $\mathrm{Cl}$ & $\mathrm{Me}$ & 7.013 \\
\hline 50. & $\mathrm{CH}_{2} \mathrm{NH}_{2}$ & $\mathrm{Cl}$ & $\mathrm{Me}$ & 6.920 \\
\hline 51. & $\mathrm{CO}_{2} \mathrm{H}$ & $\mathrm{Cl}$ & $\mathrm{Me}$ & 5.284 \\
\hline
\end{tabular}

fingerprint. These molecular fingerprints are broken into strings at fixed intervals as specified by a hologram length (HL) parameter. The HL determines the number of bins in the hologram into which the fragments are hashed. The optimal HQSAR model was derived from screening through the 12 default HL values, which were a set of 12 prime numbers ranging from 53-401. The model development was performed using the following parameters: atom (A), bond (B). The validity of the
Table 3. Structure and biological values of 1-(4phenylpiperazin-1-yl -2-(1H-pyrazol-1-yl) ethanone derivatives targeting CCR1

\begin{tabular}{cccc}
\hline & & \\
\hline Compound & $\mathrm{R}^{2 \mathrm{~b}}$ & $\mathrm{R}^{3 \mathrm{~b}}$ & $\mathrm{pIC}_{50}$ \\
\hline 14. & $\mathrm{H}$ & $\mathrm{H}$ & 8.397 \\
52. & $(\mathrm{R})-\mathrm{Me}$ & $\mathrm{H}$ & 7.431 \\
53. & $(\mathrm{~S})-\mathrm{Me}$ & $\mathrm{H}$ & 8.699 \\
54. & $(\mathrm{~S})-\mathrm{CH} \mathrm{H}_{2} \mathrm{OH}$ & $\mathrm{H}$ & 7.958 \\
55. & $\mathrm{H}$ & $(\mathrm{R})-\mathrm{Me}$ & 7.036 \\
56. & $\mathrm{H}$ & $(\mathrm{S})-\mathrm{Me}$ & 7.638 \\
\hline
\end{tabular}

model depends on statistical parameters such as $r^{2}, q^{2}$ by $\mathrm{LOO}^{[30]}$.

\section{Results and Discussion}

\subsection{HQSAR Analysis}

The HQSAR model with good predictive ability in terms of $r^{2}$ and $q^{2}$ was developed. The model was developed with Atom (A) and bond (B) parameters with $\mathrm{BHL}=151$. The selected model showed a $\mathrm{q}^{2}$ of 0.590 and an $r^{2}$ of 0.904 with 0.710 as standard error of prediction and 0.344 as standard error of estimate. The statistics obtained was found to be satisfactory. PLS results are summarized in Table 4. The actual and predicted activities of the entire dataset of molecules are given in Table 5. The graph of predicted versus actual activities for the entire dataset of molecules is shown in Fig. 1. The highest $\mathrm{q}^{2}$ value obtained for parameters $\mathrm{A} / \mathrm{B}$ was explored with an optional atom count (4-10) for further improvement of $\mathrm{q}^{2}$. A noticeable difference was observed in the statistical parameters with different atom counts for model A/B (Table 6). A standard color coding system was used to indicate atomic contributions in the HQSAR model (Fig. 2.). Unfavorable and nega-

Table 4. Statistical PLS results of HQSAR

\begin{tabular}{ccccccc}
\hline & $\mathrm{N}$ & $\mathrm{q} 2$ & StdErr & $\mathrm{r} 2$ & SEE & BHL \\
\hline HQSAR & 5 & 0.590 & 0.710 & 0.904 & 0.344 & 151 \\
\hline
\end{tabular}


Table 5. Actual and predicted $\mathrm{pIC}_{50}$ by HQSAR model

\begin{tabular}{|c|c|c|}
\hline Name & ACTUAL & PREDICTED \\
\hline CPD01 & 6.512 & 6.050 \\
\hline CPD02 & 5.251 & 5.516 \\
\hline CPD03 & 7.008 & 7.101 \\
\hline CPD04 & 6.739 & 6.037 \\
\hline CPD05 & 5.437 & 5.430 \\
\hline CPD06 & 4.494 & 4.482 \\
\hline CPD07 & 5.008 & 5.178 \\
\hline CPD08 & 5.248 & 5.081 \\
\hline CPD09 & 5.193 & 5.173 \\
\hline CPD10 & 5.481 & 5.430 \\
\hline CPD11 & 5.568 & 5.582 \\
\hline CPD12 & 4.958 & 5.739 \\
\hline CPD13 & 7.000 & 7.647 \\
\hline CPD14 & 8.397 & 7.406 \\
\hline CPD15 & 7.920 & 8.000 \\
\hline CPD16 & 7.113 & 7.424 \\
\hline CPD17 & 6.970 & 7.464 \\
\hline CPD18 & 8.301 & 8.362 \\
\hline CPD19 & 8.000 & 7.695 \\
\hline CPD20 & 7.853 & 8.020 \\
\hline CPD21 & 6.376 & 6.861 \\
\hline CPD22 & 7.284 & 6.979 \\
\hline CPD23 & 6.677 & 6.683 \\
\hline CPD24 & 6.657 & 6.499 \\
\hline CPD25 & 7.920 & 7.507 \\
\hline CPD26 & 7.795 & 7.453 \\
\hline CPD27 & 7.721 & 7.850 \\
\hline CPD28 & 8.301 & 8.313 \\
\hline CPD29 & 8.096 & 7.840 \\
\hline CPD30 & 8.154 & 7.987 \\
\hline CPD31 & 8.221 & 8.511 \\
\hline CPD33 & 7.744 & 7.583 \\
\hline CPD34 & 6.130 & 6.095 \\
\hline CPD35 & 5.958 & 5.937 \\
\hline CPD36 & 5.468 & 5.654 \\
\hline CPD37 & 8.000 & 7.870 \\
\hline CPD38 & 7.301 & 7.352 \\
\hline CPD39 & 7.327 & 7.170 \\
\hline CPD40 & 7.167 & 7.303 \\
\hline CPD41 & 6.920 & 7.149 \\
\hline CPD42 & 7.397 & 7.206 \\
\hline CPD43 & 8.096 & 7.537 \\
\hline CPD44 & 7.795 & 7.994 \\
\hline CPD45 & 7.699 & 7.464 \\
\hline
\end{tabular}

Table 5. Continued

\begin{tabular}{ccc}
\hline Name & ACTUAL & PREDICTED \\
\hline CPD46 & 8.000 & 7.578 \\
CPD47 & 8.000 & 8.134 \\
CPD48 & 6.468 & 6.689 \\
CPD49 & 7.013 & 7.482 \\
CPD50 & 6.920 & 7.124 \\
CPD52 & 7.431 & 7.668 \\
CPD54 & 7.958 & 7.978 \\
CPD55 & 7.036 & 7.425 \\
CPD56 & 7.638 & 7.425 \\
\hline
\end{tabular}

\section{HQSAR Scatter plot}

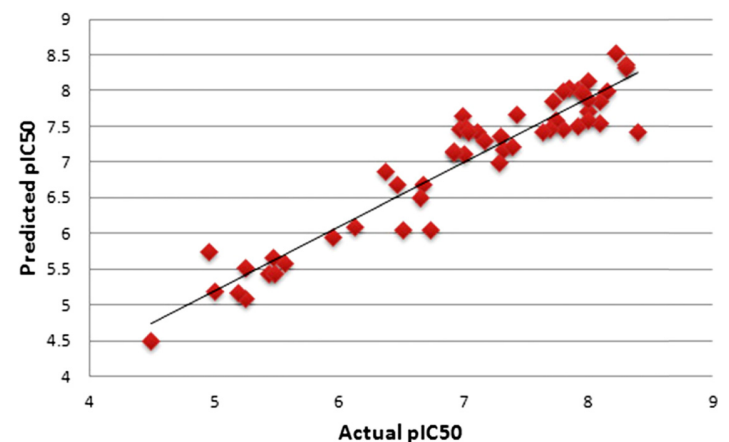

Fig. 1. Scatter plot diagram for HQSAR analysis. Plot shows the actual and predicted $\mathrm{pIC}_{50}$ of compounds.

tive contribution to the activity were denoted by red, red-orange and orange, while, yellow, green-blue and green indicated favorable or positive contribution to the activity. White showed an intermediate contribution to activity. For study of atomic contribution, molecules were selected based on their activity profile.

All the molecules in the dataset had a common substructure and varied only in $\mathrm{R}^{3}, \mathrm{R}^{4}, \mathrm{R}^{6}, \mathrm{R}^{3 \mathrm{a}}, \mathrm{R}^{4 \mathrm{a}}, \mathrm{R}^{5 \mathrm{a}}, \mathrm{R}^{2 \mathrm{~b}}$ and $R^{3 b}$ substructure. The contribution map for the highly active compound 14 (Fig. 2.) showed that the

Table 6. Statistical parameters obtained for model with different atom counts. Model with highest $\mathrm{q}^{2}$ chosen for HQSAR is marked bold

\begin{tabular}{ccccccc}
\hline $\begin{array}{c}\text { Atom } \\
\text { count }\end{array}$ & $\mathrm{N}$ & $\mathrm{q}^{2}$ & Std Err & $\mathrm{r}^{2}$ & SEE & BHL \\
\hline $4-7$ & 5 & 0.516 & 0.771 & 0.903 & 0.345 & 307 \\
$\mathbf{5 - 8}$ & $\mathbf{5}$ & $\mathbf{0 . 5 9 0}$ & $\mathbf{0 . 7 1 0}$ & $\mathbf{0 . 9 0 4}$ & $\mathbf{0 . 3 4 4}$ & $\mathbf{1 5 1}$ \\
$6-9$ & 3 & 0.515 & 0.756 & 0.771 & 0.520 & 199 \\
$7-10$ & 4 & 0.508 & 0.770 & 0.850 & 0.424 & 151 \\
\hline
\end{tabular}




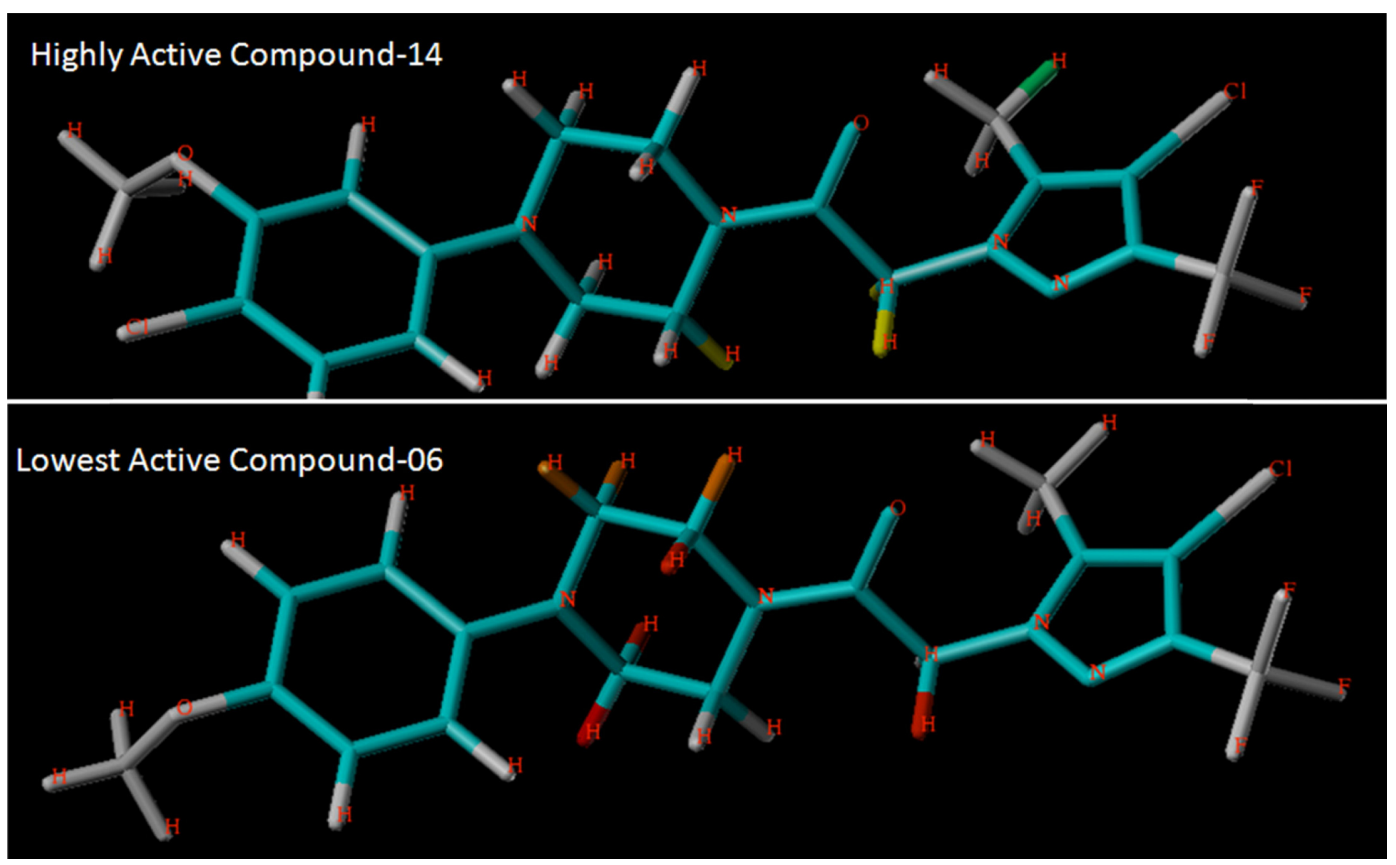

Fig. 2. HQSAR atomic contribution map. Map is shown for highly active compound-14 and lowest active compound-06.

hydrogen in $\mathrm{R}^{2 \mathrm{~b}}$ and $\mathrm{R}^{5 \mathrm{a}}$ side chain contributed positively to activity $\left(\mathrm{pIC}_{50}=8.397\right)$, whereas the remainder displayed an intermediate contribution to activity. In contrary, the contribution map (Fig. 2.) for the lowest active compound $06\left(\mathrm{pIC}_{50}=4.494\right)$ indicated that, the $\mathrm{R}^{2 \mathrm{~b}}$ and $\mathrm{R}^{3 \mathrm{~b}}$ substituent contributed negatively to the inhibitory effect while no positive contribution from the other $\mathrm{R}$ group. We have also considered few compounds from active, medium active and low active profile to see their contribution in inhibitory effect. Compound $28\left(\mathrm{pIC}_{50}=8.301\right)$, which has the second highest activity showed positive contribution from $\mathrm{R}^{6}$, $\mathrm{R}^{5 \mathrm{a}}$, and $\mathrm{R}^{2 \mathrm{~b}}$ with intermediate contribution from other $\mathrm{R}$ groups. Similarly, the compounds from the highly active series, such as compound $18\left(\mathrm{pIC}_{50}=8.301\right)$, $31\left(\mathrm{pIC}_{50}=8.221\right), 43\left(\mathrm{pIC}_{50}=8.154\right), 29\left(\mathrm{pIC}_{50}=8.096\right)$ and $47\left(\mathrm{pIC}_{50}=8.000\right)$ showed positive contribution from $\mathrm{R}^{5 \mathrm{a}}$, $\mathrm{R}^{2 \mathrm{~b}}$ and $\mathrm{R}^{3 \mathrm{~b}}$ with intermediate contribution from other $\mathrm{R}$ groups and no negative contribution from any group at all.

On the other hand, the compounds from medium active series such as compound $49\left(\mathrm{pIC}_{50}=7.013\right)$, $16\left(\mathrm{pIC}_{50}=7.113\right), 55\left(\mathrm{pIC}_{50}=7.036\right), 40\left(\mathrm{pIC}_{50}=7.167\right), 22$ $\left(\mathrm{pIC}_{50}=7.284\right), 38\left(\mathrm{pIC}_{50}=7.301\right)$ showed positive contribution in $\mathrm{R}^{5 \mathrm{a}}$ and $\mathrm{R}^{2 \mathrm{~b}}$ with intermediate contribution from the rest of the $\mathrm{R}$ groups. Whereas, compounds from low active series such as compound $12\left(\mathrm{pIC}_{50}\right.$ $=4.958), 7\left(\mathrm{pIC}_{50}=5.008\right), 9\left(\mathrm{pIC}_{50}=5.193\right), 8\left(\mathrm{pIC}_{50}=5.248\right)$, $2\left(\mathrm{pIC}_{50}=5.251\right), 5\left(\mathrm{pIC}_{50}=5.437\right)$ and $36\left(\mathrm{pIC}_{50}=5.468\right)$ showed no positive contribution in any of the $\mathrm{R}$ groups and also showed negative contribution on $\mathrm{R}^{2 \mathrm{~b}}$ and $\mathrm{R}^{3 \mathrm{~b}}$ groups with intermediate contribution in other groups. This might be the reason why these molecules are poor in activity and have less inhibitory effect.

\section{Conclusion}

The HQSAR analysis reveals that the more the positive contribution in the $\mathrm{R}$ group, the more the compound is highly active. Medium active compounds have intermediate contribution in the $\mathrm{R}$ group with one or no negative contribution. Whereas, low active compounds possess negative contribution to the most and had no positive contribution to the inhibitory effect. Fragment analyses of HQSAR can carried out as further work to avail the compound modification guidelines. This could be helpful to design a novel high active compound. The presently-developed HQSAR model aids the identification of the functional groups $\&$ atoms and highlights their importance and contribution to inhibitory potency. 


\section{References}

[1] M. Baggiolini, "Chemokines and leukocyte traffic", Nature, Vol. 392, pp. 565-568, 1998.

[2] A. D. Luster, "Chemokines: chemotactic cytokines that mediate inflammation", N. Engl. J. Med., Vol. 338, pp. 436-445, 1998.

[3] S, Segerer, P. J, Nelson, and D. Scholondorff, "Chemokines, chemokine receptors, and renal disease: from basic science to pathophysiologic and therapeutic studies", J. Am. Soc. Nephrol., Vol. 11, pp. 152-176, 2000.

[4] T. Mirzadegan, F. Diehl, B. Ebi, S. Bhakta, I. Polsky, D. McCarley, M. Mulkins, G.S. Weatherhead, J.M. Lapierre, J. Dankwardt, D. Jr Morgans, R. Wilhelm, and K. Jarnagin 'Identification of the binding site for a novel class of CCR2b chemokine receptor antagonists: binding to a common chemokine receptor motif within the helical bundle", J. Biol. Chem., Vol. 275, pp. 25562-25571, 2000.

[5] C. L. Tsou, W. Peters, Y. Si, S. Slaymaker, A. M. Aslanian, S. P. Weisberg, M. Mack, and I.F. Charo "Critical roles for CCR2 and MCP-3 in monocyte mobilization from bone marrow and recruitment to inflammatory sites", J. Clin. Invest., Vol. 117, pp. 90-909, 2007.

[6] C. Gerard and B. J. Rollins "Chemokines and disease". Nat. Immunol., Vol. 2, pp. 108-115, 2001.

[7] P. M. Murphy, M. Baggiolini, I. F. Charo, C. A. Hebert, R. Horuk, K. Matsushima, L.H. Miller, J.J. Oppenheim, and C. A. Power, "International union of pharmacology. XXII. Nomenclature for chemokine receptors", Pharmacol. Rev., Vol. 52, pp. 145176, 2000.

[8] P. M. Murphy "International union of pharmacology. XXX. Update on chemokine receptor nomenclature", Pharmacol. Rev., Vol. 54, pp. 227-229, 2002.

[9] A. Zlotnik and O. Yoshie "Chemokines: a new classification review system and their role in immunity". Immunity. Vol. 12, pp. 121-127, 2000.

[10] M. Imai, T. Shiota, K. Kataoka, C. M. Tarby, W. J. Moree, T. Tsutsumi, and M. Sudo, "Small molecule inhibitors of the CCR2b receptor. Part 1: discovery and optimization of homopiper-azine derivatives", Bioorg. Med. Chem. Lett., Vol. 14, pp. 5407-5411, 2004.

[11] W. J. Moree, K. I. Kataoka, M. M. Ramirez-Weinhouse, T. Shiota, M. Imai, M. Sudo, and T. Tsutsumi, "Small molecule antagonists of the CCR $2 b$ receptor. Part 2: discovery process and initial structure-activity relationships of diamine derivatives",
Bioorg. Med. Chem. Lett., Vol. 14, pp. 5413-5416, 2004.

[12] S. P. Weisberg, D. Hunter, R. Huber, J. Lemieux, S. Slaymaker, K. Vaddi, I. Charo, R. L. Leibel, and A.W. Jr. Ferrante, "CCR2 modulates inflammatory and metabolic effects of high-fat feeding", J. Clin. Invest., Vol. 116, pp. 115-124, 2006.

[13] C. Rolland, R. Gozalbes, E. Nicolai, M.F. Paugam, L. Coussy, F. Barbosa, D. Horvath, and F. Revah, "G-protein-coupled receptor affinity prediction based on the use of a profiling dataset: QSAR design, synthesis, and experimental validation". J. Med. Chem., Vol. 48, pp. 6563-6574, 2005.

[14] T. A. Berkhout, F. E. Blaney, A. M. Bridges, D. G. Cooper, I. T. Forbes, A. D. Gribble, P.H.E. Groot, A. Hardy, R. J. Ife, R. Kaur, K. E. Moores, H. Shillito, J. Willetts, J. Witherington, "CCR2: Characterization of the antagonist binding site from a combinedreceptor modelingmutagenesis approach", J. Med. Chem., Vol. 46, pp. 4070-4086, 2003.

[15] T. G. Marshall, R. E. Lee, and F. E. Marshall "Common angiotensin receptor blockers may directly modulate the immune system via VDR, PPAR and CCR2b". Theor. Biol. Med. Model., Vol. 3, p. 1, 2006.

[16] F. L. Mendonaca, P. C. A. Fonseca, R. M. Phillips, J. W. Saldanha, T. J. Williams, and J. E. Pease "Site-directed mutagenesis of $\mathrm{CC}$ chemokine receptor 1 reveals the mechanism of action of UCB 35625, a small molecule chemokine receptor antagonist", J. Biol. Chem., Vol. 280, pp. 48084816, 2005.

[17] N. Vaidehi, S. Schlyer, R. J. Trabanino, W. B. Floriano, R. Abrol, S. Sharma, M. Kochanny, S. Koovakat, L. Dunning, M. Liang, J. M. Fox, F. L. Mendonca, J. E. Pease, W. A. Goddard, and R. Horuk, "Predictions of CCR1 chemokine receptor structure and BX 471 antagonist binding followed by experimental validation". J. Biol. Chem., Vol. 281, pp. 27613-27620, 2006.

[18] J. Hvas, C. Mclean, J. Justesen, G. Kannourakis, L. Steinman, J. R. Oksenberg, and C. C. A. Bernard, "Perivascular $\mathrm{T}$ cells express the pro-inflammatory chemokine RANTES mRNA in multiple sclerosis lesions", Scand. J. Immunol., Vol. 46, pp. 195-203, 1997.

[19] W. J. Karpus, N. W. Lukas, B. L. McRae, R. M. Strieter, S.L. Kunkel, and S.D. Miller, "An important role for the chemokine macrophage inflammatory protein- $1 \mathrm{R}$ in the pathogenesis of the $\mathrm{T}$ cellmediated autoimmune disease, experimental autoim- 
mune encephalomyelitis", J. Immunol., Vol. 155, pp. 5003-5010, 1995.

[20] P. Rathanaswami, M. Hachicha, M. Sadick, T.J. Schall, and S.R. McColl "Expression of the cytokine RANTES in human rheumatoid synovial fibroblasts", J. Biol. Chem., Vol. 268, pp. 5834-5839, 1993.

[21] N. Snowden, A. Hajeer, W. Thomson, and B. Ollier, "RANTES role in rheumatoid arthritis", Lancet, Vol. 343, pp. 547-548, 1994.

[22] A. E. Koch, S. L. Kunkel, and R. M. Strieter, "Cytokine in rheumatoid arthritis", J. Invest. Med., Vol. 43, pp. 28-38, 1995.

[23] S. P. Raychauldhuri, W. Y. Jiang, E. M. Farber, T. J. Schall, M.R. Ruff, and C.B. Pert "Upregulation of RANTES in psoriatic keratinocytes: a possible pathogenic mechanism for psoriasis", Acta Derm. Venereol., Vol. 79, pp. 9-11, 1999.

[24] G. Kothandan, T. Madhavan, C.G. Gadhe, and S.J. Cho, "Pseudoreceptor: concept and an overview", J. Chosun Natural Sci., Vol. 3, pp. 162-167, 2010.

[25] S. J. Cho, "Recent development of search algorithm on small molecule docking", J. Chosun Natural Sci.,
Vol. 2, pp. 55-58, 2009.

[26] S. J. Cho, "Search space reduction techniques in small molecular docking." J. Chosun Natural. Sci., Vol. 3, pp. 143-147, 2010.

[27] S.J. Cho, "Calculation and application of partial charges", J. Chosun Natural Sci., Vol. 3, pp. 226230, 2010.

[28] S.J. Cho, "Meaning and definition of partial charges", J. Chosun Natural Sci., Vol. 3, pp. 231236, 2010.

[29] M. K. P. Andrew, B. A. James, S. Sen, W. Chen, Y. Xu, E. Sullivan, L. Li, K. Greenman, T. Charvat, D. Hansen, J. D. Daniel, J. J. K. Wright, and P. Zhang, "1-(4-Phenylpiperazin-1-yl_-2-(1H-Pyrazol1-yl) ethanones as novel CCR1 antagonists". Biorganic \& Medicinal Chemistry Letters, Vol. 23, pp. 1228-1231, 2013.

[30] C. G. Gadhe, T. Madhavan, G. Kothandan, and S. J. Cho, "In silico quantitative structure-activity relationship studies on P-gp modulators of tetrahydroisoquinoline-ethyl-phenylamine series", BMC Struct. Biol., Vol. 11, p. 5, 2011. 